\title{
The Battle for Business Ethics: A Struggle Theory
}

\author{
Muel Kaptein ${ }^{1}$
}

Received: 4 July 2015/ Accepted: 11 July 2015/Published online: 19 August 2015

(c) The Author(s) 2015. This article is published with open access at Springerlink.com

\begin{abstract}
To be and to remain ethical requires struggle from organizations. Struggling is necessary due to the pressures and temptations management and employees encounter in and around organizations. As the relevance of struggle for business ethics has not yet been analyzed systematically in the scientific literature, this paper develops a theory of struggle that elaborates on the meaning and dimensions of struggle in organizations, why and when it is needed, and what its antecedents and consequences are. An important conclusion is that the greater the ethics gap and opposing forces, the greater the struggle required. Viewing business ethics as struggle has several implications for theory and practice.
\end{abstract}

Keywords Ethics gap - Dilemma - Struggle $\cdot$ Virtue . Ethical behavior

\section{Introduction}

It is not only important for business organizations to become ethical (Goodstein et al. 2014; Sims 2009), but also to remain ethical. Organizations may start slipping when existing ethical norms become less embedded, but an ethics gap between what ought to be done and what is done can also arise when new ethical norms emerge, which are subsequently not fully embedded in the organization.

Muel Kaptein

mkaptein@rsm.nl

1 RSM Erasmus University, Room T11-42, P. O. Box 1730, 3000 DR Rotterdam, The Netherlands
Over the past few decades, new, more demanding ethical norms for organizations have emerged concerning bribery (Weber and Getz 2004), insider trading (Moore 1990), salaries (Nichols and Subramaniam 2001), fair trade (Jaffee 2010), the natural environment (Gladwin et al. 1995), animals (Janssens and Kaptein 2014), lobbying (Hamilton and Hoch 1997), supply chain responsibility (Van Tulder et al. 2009), human rights (Muchlinski 2012), and investing (Hudson 2005). These ethical norms are developed in response to new issues (such as bitcoins), trends (such as globalization), scandals and crisis (such as the financial-economic crisis at the end of the first decade of this century), information (such as about the damage of corruption), paradigms (such as stakeholder instead of shareholder thinking, Paine 2002), and new theories (such as an ethics of care, Lawrence and Maitlis 2012).

Besides general developments that lead to the emergence of new ethical norms for organizations, organization-specific developments can also generate new norms. For example, the production or provision of a new type of product or service, the entering of new markets and regions, a change of governance structure, and the appearance of new stakeholders may all lead to new ethical norms. To prevent an ethics gap from arising, organizations should thus not only maintain current ethical norms, but they should also adopt and embed new ethical norms.

Several factors have been cited to explain the origin of ethics gaps at organizations, such as deinstitutionalization (Oliver 1991; Westphal and Zajac 2001), decoupling (MacLean and Behnam 2010; Stevens et al. 2005), disengagement (Bandura 1999; Moore et al. 2012), rationalization, and socialization (Ashforth and Anand 2003), a decrease in quality of ethics programs (Weaver et al. 
1999a; Kaptein 2008), a decline in the ethical culture (Sims and Brinkmann 2003), and diminished attention to ethics by the board (Ocasio 1997; Weaver et al. 1999a, b). Although all of these explanations have value, the question remains as to why these factors occur. Why, for example, does decoupling take place, and why does the attention to ethics by boards diminish?

In this paper, I propose that the origin and size of ethics gaps lie in the struggle an organization and its managers and employees engage in. For this purpose, a struggle theory of ethics will be developed. The central message of this paper is that without struggling, ethics gaps will arise in organizations, and the greater the ethics gap the more the struggle will be needed. This paper therefore examines the meaning of struggle, why and when it is required, and what its antecedents and consequences are. Due to the centrality of struggle, I employ the metaphor of ethics battlefields to describe organizations.

\section{The Organization as Ethics Battlefield}

\section{Struggle}

The term struggle is frequently used in publications about the ethics of business organizations. We read in newspaper articles and reports that "The Coca-Cola Company struggles with ethical crises" (Ferrell and Fraedrich 2014), Shell is "struggling to build a better world" (Tangen 2003), and "Young bankers struggle with ethics" (Clarke 2013), or about "H\&M's struggle for ethical and sustainable fashion" (Fashion United 2014). Academic articles also cite the term struggle frequently, such as "ethics and compliance officers $[\ldots]$ struggle with internal legitimacy" (Treviño et al. 2014, p. 187), "multinational businesses [...] struggle with employment practice issues" (Treviño and Brown 2004, p. 69), and a "manager struggles with trying to find moral justified way (Velasquez 2000, p. 350). Dey (2007) uses the term in the subtitle of his article "Social accounting at Traidcraft: a struggle for the meaning of fair trade," whereas the title of Radin and Calkins's (2006) even reads "The struggle against sweatshops." A management book has also recently been published with the title "The good struggle" (Badaracco 2013). But what does the term struggle mean?

The term struggle has not been defined clearly in the academic literature; only the related concepts such as conflict—see, e.g., Boulding (1962)—are well defined. Dictionaries give us more guidance. The Oxford Dictionary defines struggle as to "strive to achieve or attain something in the face of difficulty or resistance," whereas Dictionary.com defines struggle as "to contend with an adversary or opposing force." Based on the definitions of struggle provided by these and other dictionaries, four characteristics of struggle can be distinguished.

First, there is an object at stake which is deemed valuable (cf. Badaracco 2013). People can struggle for a better environment, which implies that a better environment is valuable to them. People can also struggle against something that is undesirable, such as poverty, because there is something else they value, in this case prosperity.

Second, in a struggle, the object of value is not yet realized or guaranteed. What is valued has not been secured yet-it is something which people want to realize or preserve because its future existence is not certain. So there is a risk of losing or not realizing something valuable.

Third, the risk of losing or not being able to realize something valuable is created by adversarial or opposing forces. Those forces work against the achievement or preservation of the valued object, as opposition (Webster Dictionary) or conflict (Oxford Dictionary) is experienced (Cambridge Dictionary). There is resistance that makes it difficult or even very difficult (Oxford Dictionary) to achieve or preserve that which is valuable.

Fourth, in a struggle, dealing with opposing forces requires great effort (Cambridge Dictionary; Merrian Webster). One should, as the Oxford Dictionary states, "get free of restraint or constriction." Because of the difficulty to resist or defeat opposing forces, a struggle is not just a matter of devoting time and energy; it requires intense, demanding, tough and strenuous effort (The Free Dictionary).

Given these four characteristics, a struggle is not necessarily physical; it can also be psychological or intellectual. Neither does a struggle necessarily involve human opponents, as the opposing forces can also be nonhuman, such as evil ideologies (Adams and Balfour 1998). A struggle can be related to external forces but these forces can also be internal, such as one's own evil thoughts (Hering 1997). A struggle does not necessarily have to last long, it can also be brief-as long as it is demanding. Finally, whether a struggle is good or bad does not depend on whether the goal is to defeat the bad or achieve the good, but whether the object one is trying to realize or preserve is deemed good or bad (cf. Badaracco 2013). An ethics struggle therefore involves great effort to achieve or attain an object of value in the face of opposing forces that are difficult to resist or defeat.

\section{Pressures and Temptations}

Applying this definition of struggle to business organizations, the question is, if the ethical performance of business organizations is valuable (characteristic 1 of a struggle) and it is not attained or realized (characteristic 2), what the opposing forces are (characteristic 3), and why it requires 
great effort to resist or defeat those forces (characteristic 4). Based on research among white-collar criminals, Cressey (1953) identified two forces that stimulate people to unethical behavior, ${ }^{1}$ namely pressures and temptations (see also Tenbrunsel 1998). Pressures are forces that push people toward unethical behavior whereas temptations are those forces that pull people toward unethical behavior. Since these forces can be found in and around all organizations, and are hard to resist or defeat, every organization can be seen as an ethics battlefield.

The pressures organizations encounter have their origin in conflicting stakeholder interests and expectations. Stakeholders are those persons and institutions whose interests may be affected by the functioning of the organization (Donaldson and Dunfee 1994; Freeman 1984). They invest in the organization through different means: money as shareholders; time, expertise, and energy as employees; products and services as suppliers, and money as customers-on which all expect an acceptable return (Etzioni 1998). Other stakeholders, such as citizens living in the vicinity of an organization, are largely subject to negative impacts related to the functioning of an organization, such as noise and traffic nuisance, and therefore expect these impacts to be minimalized.

The interests and expectations of different stakeholders can conflict with one another (Neville and Menguc 2006). As the business environment is not munificent (Staw and Szwajkowski 1975), organizations have to compete for resources in the labor market (for employees), financial market (for capital), supply market (for materials), and customer market (for sales). Within a business organization, scarcity is also a factor, in the sense that time, money, knowledge, and attention is limited (Cyert and March 1963; Hambrick and Snow 1977; Ocasio 1997). As a result, all stakeholder expectations cannot be fully realized at the same time. The organization has to make choices as to which interests to honor (more), or less-or not at all (Hill and Jones 1992). These choices, often accompanied by dilemmas, are inevitable given that scarcity is an inherent feature of the economic system (Kaptein and Wempe 2002).

Faced with dilemmas, people in organizations may feel under pressure to meet interests and expectations of stakeholders which cannot be fully met. Furthermore, when stakeholders know that there is a risk that their interests and expectations will not be fully met, they may exert more pressure on the organization to meet their demands (Mitchell et al. 1997). Research also shows that

\footnotetext{
${ }^{1}$ Cressey (1953) found rationalization to be a third explanatory factor. Since it is not an external force, it is not included here. Casey's other factor, opportunity, will be restricted to temptation because we are only interested here in the part that stimulates unethical behavior.
}

many organizations often operate under very high pressure (González-Benito and González-Benito 2010; Sjöström 2008; Waddock et al. 2002). For example, Martin et al. (2007) found that when organizations vie with competitors for scarce resources, they experience heightened pressure to succeed and to survive (cf. Baucus and Near 1991).

Given these pressures on organizations, the temptation exists to not balance all stakeholder interests and expectations in an ethical manner, but rather to honor most of those stakeholders who exert the most pressure on the organization (Pfeffer and Salancik 1978). Likewise, it also easier and therefore tempting to honor more of those stakeholders who are most important for the organization as it best serves the interests of the organization. In a similar vein, it can be tempting to disproportionally honor the interests of those stakeholders who are served by shortterm, direct, certain (financial) results; it is more visible, and therefore easier than pursuing long-term, indirect, uncertain, and nonfinancial interests (cf. Fishbach and Shah 2006; Keizer 2010).

Temptations can be found not only around organizations but also within them. The very nature of organizations gives rise to different internal temptations to engage in unethical behavior. The division of labor is a defining feature of organizations (Smith 2009), and while clearly defined tasks increases efficiency, it also harbors the temptation of excessive individualism, where people focus exclusively on their individual tasks even if it causes harm to others or would be better to do other things (cf. Simons and Chabris 1999; Staw and Boettger 1990). The hierarchical structure of organizations brings with it another temptation, namely conformity. It involves following orders even if it is unethical or it would be better to do other things, purely because 'this is the way organizations work' (cf. Litzky et al. 2006; Milgram 1974). Another temptation comes with the authority people are given in organizations to perform certain tasks and the corresponding opportunity to misuse it (De Cremer et al. 2009; Pitesa and Thau 2013). A final example of an internal temptation concerns the risk of goal displacement, which arises when the organization is perceived as a goal in itself rather than a means to serve the interests and expectations of stakeholders (Kerr, 1975).

\section{Human Vulnerability}

Pressures and temptations are inherent to the functioning of markets, organizations, and stakeholders, but it does not explain why it is difficult to resist or defeat these forces. If pressures and temptations are like heat and oxygen, there has to be fuel to have a fire (cf. Albrecht et al. 2008). For unethical behavior to exist, humans have to engage in 
unethical behavior. Humans succumb to unethical behavior because they are vulnerable to pressures and temptations.

The question whether human beings are inherently good or bad is one of the oldest in the history of intellectual thought and many a philosopher, political scientist, and theologian have articulated their different views (cf. Kinneging 2009; Messadié 1996; Neiman 2004). According to Augustine (1982), people are inclined to do evil; humans suffer from a deficiency, both cognitive and conative, thus crude human nature should be conquered. For Machiavelli (1992), humans are inclined to do bad rather than good; they will act on their evil instincts whenever the opportunity arises, and they will only do good if circumstances force them to. For Spinoza (1985), to conquer evil or to be released from it belongs to the deeper motives of human behavior. For him, humans are offenders and victims at the same time. According to Kant (1785/2002), all humans have the capacity for good and evil; every human being has the potential to do evil deeds in the face of temptation. According to Kant, however, the capacity for evil deeds can be overcome, given that the capacity to do good is not extinguishable. According to Hobbes (1928), the human heart is the seat of multiple contending passions, but the unbeatable passion is called the will. Hume (2012) offers one of the most positive views, given that for him every human being is capable of altruism and benevolence. What these and other theories on human nature underscore is the vulnerability of human beings to pressures and temptations.

Empirical research in (social) psychology, criminology, behavioral economics, and behavioral business ethics confirms this vulnerability in humans. Pioneering experiments have shown that "ordinary people" who are generally perceived to be good (Zimbardo 2007, p. vii) are capable of grossly unethical behavior. The experiments of Ash (1955) have shown that the social pressure of a group can make people lie, whereas Milgram (1974) has shown that under pressure to carry out the instructions of an authority figure, a high number of people are capable of administering deadly shocks to another. Zimbardo (2007) has shown that the pressure to conform to a particular role can lead people to mistreat others. More recent experiments in laboratory settings, such as having the opportunity to commit fraud during exams (Mazar and Ariely 2006) and stealing money (Mazar and Zhong 2010), as well as field experiments with lost wallets (Wiseman 2011) and receiving too much change (Azar et al. 2013), indicate that human beings are susceptible to pressures and temptations.

That people are vulnerable to pressures and temptations need not to be considered as a gloomy state of affairs. Being susceptible does not necessarily imply that people always do bad things. Aristotle (Rowe and Broadie 2002) taught that while humans are confronted with conflicts that pull them in different directions, they ought and are able to strive for the middle road. Mead et al. (2009, p. 597) even speak of human beings being torn between "taking what they can get away with and doing what is socially valued and appropriate." However, as Kant (1785/2002) posited, that people are inclined to do bad things does not mean they are doomed to do bad things. If that were the case, people would do bad things whenever the opportunity arises. Empirical research also shows that people are willing and able to act ethically in the face of temptation (Dovidio et al. 2006; Gintis et al. 2003). Thus, although people are vulnerable to pressures and temptations to behave unethically, they are at the same time not doomed to unethical behavior. This creates room to resist pressures and temptations, and this is where struggle comes into view. $^{2}$

\section{Dimensions of Ethics Struggle}

\section{Objects of Ethics Struggle}

Pressures and temptations to behave unethically, and the human susceptibility to them, make it difficult to resist or even defeat these forces. For this reason, organizations face an ethics battle, and this struggle has three objects.

First, there is the struggle against unethical behavior to avoid sliding downhill. Organizations have to combat pressures and temptations that threaten existing ethical norms. The temptation to succumb to the threat new developments pose, and lapse into unethical practices, has to be pushed back. For example, organizations may face pressures from the stock market to increase their profits and be tempted to lower the quality of products, pay bribes to get new business, or commit accounting fraud. Martin et al. (2007), for example, found that the tougher the competition, the more likely organizations are to resort to unethical behavior to undermine their rivals.

Second, there is the struggle for ethical behavior in order to move uphill. As noted in the introduction, new ethical norms can emerge as a result of general or specific developments. However, organizations can face opposing forces in their attempt to adopt and implement them, which should be combatted. Resistance to the adoption and implementation of new norms can arise because of its

\footnotetext{
${ }^{2}$ Pressures and temptations are not by definition bad in themselves. For example, an attractive colleague is not bad because his or her appearance may be a temptation for others. Pressures and temptations can also stimulate ethical behavior. Machiavelli (1992) posits that certain pressures make us to do good things, such as peer pressure. Weaver et al. (1999a, 1999b) also note the pressures organizations confront to do ethical things. Hence, although this paper focuses on pressures and temptations to do unethical things, it is not to deny the existence of pressures and temptations to do ethical things.
} 
potential to change the current distribution of power and benefits (Piderit 2000; Thomas et al. 2011). Dey (2007) describes the struggle at Traidcraft Plc where the introduction of fair trade principles led to a conflict with the imperatives of operating as a commercial enterprise, and where the latter won. Regarding this type of struggle, Graetz and Mashaw (1994) talk of a moral crusade, which they describe as a struggle over both the right and the good.

Third, there is the struggle with ethical dilemmas. Organizations are not only required to struggle against evil and for the good, they can also be confronted with situations in which they have to choose between two or more good things (Badaracco 1997) or between two or more bad things (Leibniz 2000). MacIntyre (1984) observes that it is not only possible for ethical virtues to be rivals, they can even be at war with each other. For Morgan (1986, p. 127), organizations often have "competing value systems" from which dilemmas arise. Such dilemmas cause an ethics struggle when it is unclear as to what the ethical thing is to do. Graafland et al. (2006) have collected different types of ethical dilemmas executives wrestle with and they illustrate how difficult it is to resolve these dilemmas and how painful the decision-making process can be.

\section{Other Dimensions}

To be able to study the struggle organizations are engaged in, we have to identify the different dimensions of ethics struggles. Next to the objects of a struggle as described above, a struggle can vary in terms of location, duration, intensity, and strategy.

\section{Location}

As mentioned above, a struggle can take place between people or within a person. A struggle between people can take place within the organization, for example, within a team or between teams, hierarchical levels, or different functions (e.g., the backoffice with the front office), or parties external to the organization can be involved, such as societal stakeholders.

\section{Duration}

The duration of a struggle concerns the period a struggle spans. A struggle can, for example, take place in one meeting when opponents need to be persuaded, or for many years, as in the case of certain multinationals that opposed South Africa's apartheid regime during the 1980s. Ciulla (2011) even refers to ethics as a constant struggle. The duration of a struggle is not equal to its intensity, as it is likely to fluctuate.

\section{Intensity}

The intensity of a struggle refers to the dedication of the different parties to the struggle. Such dedication can be expressed through the time, money, energy, and attention devoted (cf. Kahneman 1973; Weick 1995). As mentioned above, struggle requires great effort; it demands suffering and sacrifice. This is the case when the struggle is accompanied by uncertainty, risk, emotional concern, and discomfort. For example, terminating a very lucrative business relationship for ethical reasons can be a financial blow, elicit strong criticism, and raise serious doubts about having made the right decision. Or, to give another example, assigning greater authority to ethics officers in an organization can provoke annoyance from managers who may feel that it undermines their autonomy. The intensity of a struggle multiplied by its duration represents the magnitude of a struggle.

\section{Strategy}

The strategy that is pursued in a struggle can also vary. The literature on self-control presents several strategies to deal with the temptations of smoking, overconsumption, and adultery (cf. Fishbach and Converse 2010; Vohs and Baumeister 2011), whereas the military science literature presents a variety of strategies to deal with enemies (Greene 2007; Heuser 2010; Von Clausewitz 2004). Four main strategies can be identified to deal with pressures and temptations. First, there is the offensive strategy, where the struggle consists in eliminating (Wertenbroch 1998) or attenuating (Ayadi et al. 2013) pressures or temptations, whether at their root or at their point of impact. Examples of this strategy include laying off employees who refuse to improve their ethical behavior, decreasing bonuses, and locking valuables up in a safe. Another strategy is the escape strategy, or what Ayadi et al. (2013) refers to as avoidance. In this strategy, the struggle consists in trying to escape from pressures or temptations by, for example, withdrawing from a country where human rights violations are at the order of the day, and splitting up functions that combine conflicting responsibilities. By contrast, the reconciliation strategy, as propagated by Hampden-Turner and Trompenaars (2008), aims to turn pressure and temptation to behave unethically into an incentive to behave ethically, such as making ethical performance a criterion for receiving bonuses, making agreements with competitors to sell ethical products, and turning the biggest opponent to a new ethics policy into the biggest proponent. Apart from turning opposing forces around, or moving away from them, there is also another strategy. The strategy of resistance requires facing temptations and pressures and not to be influenced by them. This strategy can be 
likened to Shiffman's (1984) advice on coping with the temptation to smoke: by finding substitutes and distractions, thinking about the negative effects of smoking, or the positive consequences of not smoking. Trope and Fishbach (2000) suggest self-imposed penalties and rewards as a way to resist temptations. In the context of organizations, this strategy translates, for example, into developing a business code of ethics, having a robust monitoring and control framework, and running an ethics training program.

\section{A Model of Ethics Struggle}

Having discussed the nature of ethics struggles in organizations, their different dimensions and why they are required, the question arises as to what their antecedents and consequences are. Figure 1 presents a simple model of the antecedents and consequences of ethics struggles (with the number of the proposition in brackets) that are discussed in this section. ${ }^{3}$

\section{Magnitude of Struggles}

\section{Pressures and Temptations}

It has been argued above that organizations have to struggle to remain ethical due to the existence of pressures and temptations. The magnitude of a struggle depends on the intensity and duration of the pressures and temptations; the greater and longer the pressures and temptations, the more the struggle that is required. Liu et al. (2014), for example, note that when an organization expands, its structure becomes more complex. Competing goals between units can generate conflicts, increasing the frequency of temptations for opportunistic behaviors. Such an increase in pressures and temptations would require, ceteris paribus, greater struggle to prevent (the widening of) an ethics gap. The first proposition therefore is

Proposition 1: The greater the pressure and temptation to behave unethically, the greater the struggle required.

\footnotetext{
3 The negative impact of a struggle on the magnitudes of the pressures and temptations will not be discussed in this section as it has already been noted in the previous section that some strategies of struggle aim to reduce the pressure and temptation. Also the relation between individual combativeness and organizational combativeness will not be worked out into a proposition as organizational combativeness will be introduced as positively influencing the combativeness of individual members of an organization, whereas individual combativeness can create and improve organizational combativeness.
}

A model for ethics struggle

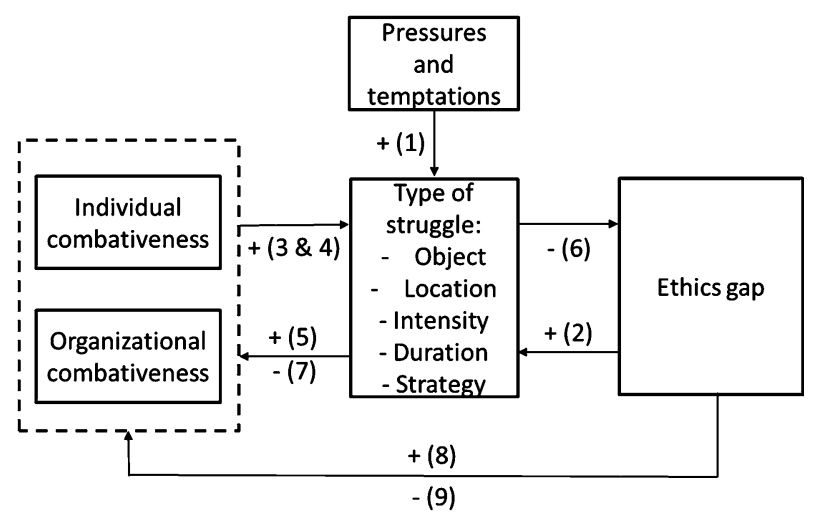

Fig. 1 A model for ethics struggle

\section{Ethics Gap}

The magnitude of a struggle is also determined by the ethics gap. The bigger the ethics gap, the greater the need for struggle to bridge that gap. As the distance between the current situation and the desired situation becomes larger, the road is longer, and more effort is required to succeed. For example, it is more of a struggle to convince all employees instead of one percent, to reduce $\mathrm{CO}_{2}$ emissions with fifty percent instead of one percent; and to improve the ethical performance on human rights, to put in place a sustainable supply chain as well as systems to ensure transparency than it is to improve only one of these areas. The second proposition therefore is

Proposition 2: The bigger the ethics gap, the greater the struggle required.

\section{Conditions for Struggle}

How do we explain the type of struggle organizations and people engage in? Virtue ethics focuses on the desirable characteristics or qualities to ensure success (MacIntyre 1984). In Greek antiquity, virtues were strongly associated with the qualities and characteristics required to be successful on the battlefield. Viewing organizations as a battlefield thus requires identifying those virtues that will enable organizations and people to struggle successfully. An important requirement for struggle is combativeness. Combativeness is therefore a desirable characteristic of individuals as well as organizations for engaging in struggle.

\section{Personal Combativeness}

In order to struggle, managers and employees should possess the quality of combativeness. Muraven et al. (1998) 
present and test a strength model for individuals to cope with temptations. Baumeister and Exline (2000) even regard strength, which they (Baumeister and Exline 1999) liken to a muscle, as the most important virtue. Although strength is an important characteristic of combativeness, there are also other important characteristics. Research that has been conducted on self-control (Baumeister and Exline 1999), self-efficacy (Bandura 1994), and self-regulation (Boekaerts et al. 2005) is especially helpful in defining these characteristics.

The first characteristic of combativeness is wisdom. Wisdom is one of the cardinal virtues in the Western philosophical tradition (Carr 1988; Moberg 1999) and is also an important condition for meaningful struggle. Aristotle (Rowe and Broadie 2002) alerted us to the risk of striving toward evil, while we think it is good. For a struggle to be good or ethical, it is important to be aware of the ethical norms we depart from and those we strive toward. Furthermore, knowledge and insight are important in order to take wise decisions about when and where struggle is called for, and which strategy to deploy.

The second characteristic of combativeness is strong moral conviction. While wisdom concerns knowledge, moral conviction is about how deep this knowledge is rooted. Integrity implies standing for something which in turn requires a solid foundation, that is, to be firmly rooted. As Kaptein and Wempe (2002) argue, a person of integrity has a set of steadfast beliefs that define who they are and what they stand for. Unlike the moral chameleon, external forces do not sway them. The more strongly someone stands for something, the more that person can be said to have integrity (Calhoun 1995). It implies a commitment to convictions that enables the individual to face pressures and temptations that threaten to undermine those convictions. The stronger a person's convictions, the more it is intertwined with their identity, and the more they will protect it and strive to integrate them with new related norms. As Erikson (1993) states, a person with integrity accepts responsibility for their actions and rarely appeals to external forces to explain or justify their behavior.

The third characteristic of combativeness is self-control, what Aristoteles referred to as enkrateia (as opposed to a lack of self-control, akrasia). For Aristotle, self-control or the disciplining of desires is the first goal of human moral development. De Ridder et al. (2012, p. 77) define selfcontrol as "the capacity to alter or override dominant response tendencies, and to regulate behavior, thoughts, and emotions." Self-control is required in order not to be influenced by temptations and pressures, or at least to refrain from engaging in unethical behavior in the face of pressures and temptations. Gottfredson and Hirschi (1990) provide evidence that low self-control is an important factor in producing criminal and antisocial behavior.
LaRose and Eastin (2002) show that self-control is required in order to deal with temptations in a rational manner.

The fourth characteristic of combativeness is willpower. As Sekerka and Bagozzi (2007) put it, willpower refers to the strength of will to face and resolve ethical challenges and to confront obstacles that may stand in the way of proceeding with the right action. Willpower is the motivational strength to remain and become ethical. Willpower differs from self-control in that it promotes or drives desirable behavior (it moves us forward on the track) whereas self-control prevents undesirable behavior (it helps us stay on track by not being diverted). Having willpower is not only about having the strength to deal with opposing forces, but also about being able to persevere or persist for as long as necessary in the face of struggle.

Courage is the fifth characteristic of combativeness. Someone may have willpower but still fail due to being overwhelmed by fear at a critical moment. Courage is essential, which does not imply not having any fears, but having the capacity to overcome fear (Woodard 2004). Sekerka and Bagozzi (2007, p. 135) define moral courage as "the ability to use inner principles to do what is good for others, regardless of threat to self, as a matter of practice." For them, moral courage is central to human flourishing as individuals struggle with their desires. Kidder (2005, p. 7) defines moral courage as "a commitment to moral principles, an awareness of the danger involved in supporting those principles, and a willing endurance of that danger." Courage is the readiness to endure danger and to "resist temptations and social pressures" (Hannah et al. 2011, p. 555) for the sake of remaining or becoming ethical (cf. Koerner 2014).

The sixth characteristic of combativeness is confidence. According to Armitage et al. (2014), self-efficacy has been operationalized in two principal ways in the literature: some studies operationalize self-efficacy as 'global selfefficacy,' which captures general feelings of confidence in one's ability to achieve goals, such as losing weight, whereas other studies focus on 'self-efficacy for temptations' which assesses people's confidence in their ability to overcome temptations, such as situations in which diets are harder to follow. In both respects, confidence in one's combativeness is important to battle or struggle successfully. As Bandura (1977, p. X) puts it: "In order to succeed, people need a sense of self-efficacy, strung together with resilience to meet the inevitable obstacles and inequities of life."

The seventh characteristic of combativeness is skill. Dohm et al. (2001) found that the key difference between weight maintenance success and failure was the skill to deal with lapses. For De Ridder and De Wit (2006), a fundamental part of self-regulatory behavior is the ability to develop goal-setting skills. Being equipped with the 
right skills is important in order to engage the other aspects of combativeness at the right moment, in the right proportion, and in the right manner. In war, battles are won on a tactical level through using the right skills (Greene 2007; Shalit 1988).

To conclude, each of the above seven characteristics of combativeness are expected to improve an ethics struggle on each of its dimensions. This leads us to the next proposition:

Proposition 3: The more the managers and employees embody the seven characteristics of combativeness discussed above, the better they struggle.

\section{Organizational Combativeness}

Combativeness is also an organizational virtue. Kaptein (2011) has developed a model for organizational virtues based on the argument organizations can be seen as moral entities. The Corporate Ethical Virtues Model-abbreviated as CEV model-formulates organizational conditions for managers and employees to behave ethically. This model is also helpful in delineating the organizational conditions for managers and employees to struggle successfully.

The first characteristic of organizational combativeness is clarity. In the CEV model, clarity concerns the extent to which the organization makes clear to managers and employees what kind of ethical behavior is expected of them since vagueness and ambiguity are potential antecedents to unethical behavior. In terms of struggling, this means that when the organization makes clear to managers and employees what the ambition, vision, and strategy of the organization are, managers and employees are stimulated to struggle as they know why and in which areas struggle is required. Research shows that individuals deal better with pressures and temptations if they have clear goals (Pearson 2012; De Ridder and De Wit 2006). It follows that an organization with clear goals would help employees to struggle better.

A second characteristic of organizational combativeness is role modeling. Managers are important role models within organizations, as employees learn from them what behavior is expected by observing their behavior (Brown et al. 2005). Accordingly, role modeling is one of the virtues of the CEV Model. Applied to struggling, the more the management head and lead the struggle, the more the employees are stimulated to follow suit. Furthermore, the less the management struggle, the less the employees will be motivated engage in ethical struggles.

A third characteristic is achievability. In the $\mathrm{CEV}$ model, this refers to the extent to which employees have sufficient time, budget, equipment, information, and authority at their disposal to fulfill their ethical responsibilities. Having insufficient resources not only brings about unethical behavior (Schweitzer et al. 2004), it also diminishes the scope for managers and employees to struggle. Research has shown that in order to resist temptations, individuals need sufficient energy (cf. Muraven et al. 2006; Tyler and Burns 2008). Barnes et al. (2011) also found that unethical behavior can (in part) be related to lack of sleep, which corresponds with the findings of Christian and Ellis (2011) that theft and interpersonal deviance can be associated with sleep deprivation. Hence, the better an organization is at providing managers and employees the resources they need to struggle, the better the employees are able to struggle.

A fourth characteristic of organizational combativeness is commitment. The CEV model proposes commitment as desirable because an organization characterized by demotivation, mistrust, and dissatisfaction can be a breeding ground for unethical behavior. The more effort an organization makes to motivate and instill loyalty among managers and employees, the more likely it is that they will behave ethically (Tyler and Blader 2005). Applied to the idea of struggling, this means that the more commited people are to an organization the more motivated they are to struggle, and the more likely it is that they will struggle. Managers and employees are, for example, motivated by convincing and inspiring stories about why ethics and struggling are relevant and also necessary. In organizations characterized by internal distrust, managers and employees are less likely to struggle together as mutual trust is an important prerequisite for collaboration (Jones and George 1998).

A next characteristic of organizational combativeness is transparency. In the CEV-model, transparency or visibility refers to the degree to which (un)ethical behavior, and its consequences are observable to those who can act upon it. Several studies have shown the importance of transparency because of its potential to expose unethical behavior and act as deterrent owing to the increased likelihood of getting caught (see, e.g., Cressey 1953). Research has demonstrated that mindfulness can enhance self-control in the face of pressure and temptations (Masicampo and Baumeister 2007). Mindfulness involves the cultivation of awareness of physical signals as well as sensory experiences, thoughts, and emotions (Brown and Ryan 2003; Weick and Sutcliffe 2006). This individual ability to self-monitor is a key element in developing successful self-regulation (De Ridder and De Wit 2006). Applied to organizations, mindfulness implies, for example, monitoring developments that may require new ethical norms. Such developments would generate new pressures and temptations-and struggleswhich also need to be monitored as they become manifest individually and collectively. 
Another characteristic of organizational combativeness is discussability. Discussability in the CEV model refers to the openness in the organization to discuss ethical dilemmas and alleged unethical behavior. In their publication named 'Identifying and battling temptation,' Fishbach and Converse (2010) emphasize the importance of identifying conflict. According to them, people succumb to temptation because of a failure to realize that their actions will be harmful. Applied to organizations this means that within organizations, current and potential conflicts are discussed so that managers and employees become more aware of these conflicts, their consequences, and the need to adequately deal with them. Another application of the viewpoint of Fishbach and Converse is that employees can raise the issues they experience in their struggle and the struggles of others. For example, if colleagues who cease their struggle cannot be called to account it signals that struggling is not necessary which will undermine the combativeness of managers and employees. Furthermore, if they cannot raise ethical issues they are struggling with, they are left to their own combativeness and the potential advantage of joint struggle is missed.

A final characteristic of organizational combativeness is sanctionability. Sanctionability or reinforcement in the CEV model refers to the likelihood of employees being punished for unethical behavior and rewarded for ethical behavior. Because rewards and punishment are important behavioral stimuli, rewards tend to lead to repetition and punishment to avoidance (Treviño et al. 2006). This not only holds for ethical behavior in general but also for struggling. Research by Trope and Fishbach (2000) shows that individuals who reward themselves for resisting temptations are better at resisting those temptations. Organizations can also reward employees for resisting opposing forces and impose punishment for failing to do so. Organizations can also celebrate victories and express regret when incidents occur.

To conclude, the above characteristics of organizational combativeness are expected to improve an organization's struggle. This leads to the next proposition:

Proposition 4: The more an organization embodies the seven characteristics of combativeness discussed above, the better the managers and employees struggle.

\section{Development of Combativeness}

The concept of struggle becomes more relevant from a managerial and normative perspective if combativeness can be developed as a virtue. For Aristotle (Rowe and Broadie 2002), virtues can be developed. Using their muscle analogy, Baumeister and Exline (1999, 2000) hold that virtues for self-control can be developed like muscles. The organizational virtues the CEV model articulates can also be developed given that, as Kaptein (2011) argues, virtues can only be called virtues if they can be improved.

One way that virtues can be developed is through practice. Aristotle wrote that habituation or ethismos (ethos) follows from repetition; through the disciplining of desire, painful things become pleasant, and brings into being a second nature (êthos). Baumeister and Exline's use of the muscle analogy is to demonstrate that self-control grows stronger with practice. Research by Muraven et al. (1999) also shows that people who performed a series of self-control exercises over several weeks were subsequently more resistant to new temptations. Muraven (2010) found that the ability to exercise self-control improves with regular practice of small acts of self-control. Research has also shown that the regular performance of tasks requiring self-regulation can increase willpower (Gailliot et al. 2007; Oaten and Cheng, 2007).

Combativeness can also be developed through struggle in real-life situations. As Moore (1907) points out, struggle makes one stronger; battling opposing forces builds strength to battle even greater opposing forces. Winning small battles builds confidence to win bigger ones; provides an opportunity to learn from mistakes and avoid them in bigger and potentially more fatal battles; provides experience to deal with more complex struggles; and increases resilience against greater pressures and temptations. Just like a muscle develops through the painful damaging of fibers, so the endurance of pain can increase combativeness. This "pathei mathos," which was propagated by Aeschylus, means that suffering chastens, and that one learns through suffering (Jardine et al. 2014).

The development of combativeness does hold not only for individuals but also for organizations. Organizational virtues become embedded through practicing them. For example, by regularly discussing issues surrounding particular ethical struggles, the virtue of organizational discussability becomes more entrenched. As muscles become stronger by gradually increasing resistance-for example, by lifting an extra kilo each month-organizational combativeness can also grow through a gradual increase in exposure to pressures and temptations. The fifth proposition reads as follows:

Proposition 5: The more the struggle is engaged in, the more the individual and organizational combativeness will grow.

\section{Consequences of Struggle}

\section{Ethics Gap}

The objective of an ethics struggle is to remain or become ethical. Winning battles and successfully dealing with the 
opposing forces are meant to result in ethical behavior. However, a struggle can also lead to defeat, a decline in ethics, and unethical behavior, if the struggle-in terms of the above described dimensions of a struggle-is insufficient or wrong, which could be the result of a lack of personal and organizational combativeness. Therefore, an ethics struggle as such is no guarantee for an ethics victory. However, the better the struggle is, the more likely that the ethics gap will become smaller, disappear or does not even appear.

Besides the fact that struggle is laudable because it leads to ethical behavior, struggle is also ethical in itself as it demonstrates the recognition of a given ethical norm, the need to protect or realize the norm, and the willingness to fight against the pressures and temptations that threaten upholding or adopting that norm. In keeping with Kant's (1785/2002) deontological ethics, engaging in ethics struggles can be seen as a moral imperative because it is the right thing to do. Struggle is therefore valuable in itself. As Pascal (1910, p. 2) asserted: "The struggle alone pleases us, not the victory." Struggle is also virtuous as it demonstrates the virtue of combativeness, and it is only in struggle that one can show one's combativeness. Engaging in struggle is also virtuous as it demonstrates the value one attaches to becoming or retaining ethicals. As Aristotle pointed out, if being virtuous were always easy, we would not praise it (Duska 2000). In that sense, struggling gives insight into the meaning of ethical behavior.

Does this mean that when struggle is absent, ethics is also absent? In situations where all pressures and temptations have been defeated or where organizations and managers and employees have become immune to them, no struggle would indeed be needed. However, the complete absence of opposing forces or complete immunity to those forces exists only in an ideal world; organizations operate in an imperfect world, rife with tensions, risks, and deficiencies. Moreover, even if there is a balance or equilibrium in the realization of stakeholder interests the challenge always remains to do more or better. As long as an organization damages or does not fully realize the legitimate interest of at least one of its stakeholders, there is room and reason for struggle. Therefore, if struggle is absent, the realization of the legitimate interests of stakeholders is not being pursued in the best manner possible. To conclude, the next proposition is:

Proposition 6: The better the struggle is, the smaller the ethics gap will be.

\section{Struggling and Combativeness}

As discussed above, practicing resistance of temptations through struggle can improve personal and organizational combativeness. However, struggling may also lead to a decrease of combativeness, such as the ethics officer who left the organization after she became too tired of struggling to obtain a bigger budget and more attention from management. Ego depletion theory (Baumeister and Heatherton 1996) posits that self-control is a finite resource that can be depleted. Research demonstrates that resisting temptations requires exertion, which leads to fatigue and consequently to temporary decreases in self-regulation, and a higher susceptibility to engage to other types of unethical behavior (Gailliot and Baumeister 2007; Gino et al. 2011; Mead et al. 2009, Muraven et al. 1998). If resources are taxed too much, struggling can thus lead to a decrease in combativeness. This holds both on individual as well as organizational level. For example, when an organization invests a lot of resources into recovering from an ethics crisis, members of the organization may become exhausted, and the resources may run out. As a consequence, both the support for ethics (organizational commitment) and the available means (organizational achievability) decrease. This results in the following proposition:

Proposition 7: An ethics struggle leads to less combativeness if one or more of the characteristics of combativeness are decreased or depleted.

\section{Ethics Gap and Combativeness}

Defeat in an ethics struggle creates an ethics gap, which can lead to an even bigger gap. A bigger ethics gap is caused by, for example, a decline in willpower as a result of defeat. Unethical behavior can impact negatively on an individual or organization's self-image (as becoming or remaining ethical). In order to restore this damaged selfimage, the individual or organization could attach less importance to ethics, thus increasing the risk of further unethical behavior (cf. Shao et al. 2008). Also, the greater this gap, the more combativeness is required to bridge the gap, the realization of which may lead to reduced confidence in the organization or individual's ability to close that gap.

However, an ethics gap can prompt management to take action to bridge the gap. The greater the gap, the more visible the gap and its current or potential negative impact, thus the more likely it is to receive attention from management due to the urgency to improve the situation (Ocasio 1997). Succumbing to the temptation to rationalize a smaller gap-as a mistake, an incident, or the case of one rotten apple-is easier than in the case of a large gap (Tenbrunsel and Messick 2004). Although large gaps can also be rationalized, for example, with the argument that "everyone is doing it" or "without it business is impossible," it is more difficult because it requires a more 
extensive rationalization. Organizations and individuals may therefore be more willing to struggle when greater effort is required, such as in the event of an ethics crisis prompting the implementation of a new business model, than when less effort is required.

The absence of an ethics gap can also lead to less combativeness because it could create the impression that everything is under control. This can lead to ethics receiving less attention, while more attention is being paid to other issues (Ocasio 1997). The absence of an ethics gap could even lead to complacency, especially in the face of the false belief that an individual or organization has become undefeatable, which can result in a significant decrease in the awareness that struggling remains important. When an ethics gap is (almost) entirely absent, the pressure to decrease efforts in order to achieve the same results more efficiently is likely to occur. When unethical behavior is (almost) absent, it becomes harder to justify the investment of resources because little or no damage is being caused by unethical behavior. The absence of an ethics gap may therefore lead to a reduction in attention to ethics, thereby increasing the risk of unethical behavior occurring. The final two propositions therefore are

Proposition 8: An ethics gap that creates an increase in combativeness leads to an increase in struggle.

Proposition 9: An ethics gap that causes a decline in combativeness leads to a decline in struggle.

\section{Discussion}

This paper has presented a first outline of a theory of ethics struggle to explain the occurence and frequency of unethical behavior in organizations. One reason why organizations fail to adopt new ethical norms or maintain existing ethical norms is that managers and employees do not struggle sufficiently. Managers and employees need to struggle because they are faced with pressures and temptations in their work which they are susceptible to. To argue that ethics struggles are unnecessary is to deny the flawed nature of organizations and human beings as well as the nature of ethical norms which is that they are subject to change.

In this paper, a basic model has been developed to describe the dimensions, conditions, and consequences of ethics struggles in and by organizations. To recapitulate, the dimensions of an ethics struggle are object, location, duration, intensity, and strategy: its conditions are personal and organizational combativeness; and the consequences of an ethics struggle are defeat (the creation or increase of an ethics gap) or victory (the decrease or dissolution of an ethics gap and the adoption of new norms). The virtues of both personal combativeness and organizational combativeness comprise seven characteristics. The more combative the organizations and the individuals are the better they are able to struggle, and the more likely ethics gaps will become smaller, disappear, or be prevented. One way to develop combativeness is through struggling.

The proposed theory of struggling is both pessimisticgiven the existence of pressures and temptations, as well as the human proclivity to do evil-as well as optimisticgiven that organizations and individuals have a capacity to struggle, and combativeness can be developed and struggling can indeed lead to a reduction in unethical behavior and an increase in ethical behavior. The proposed theory is also both positive, in that it presents a model to explain ethical and unethical behaviors in organizations, and normative, in that it presents ethical norms for what organizations and individuals should be (combative) and do (struggle). The proposed theory is also multilevel; organizational combativeness and struggling may influence individuals, but individuals' combativeness and struggling may also influence organizations.

Struggle theory contributes to business ethics literature in at least two ways. First, struggle theory presents a new view of organizations, namely the organization as a battlefield. Morgan (1986) points out that our view of organizations influences our analyses, findings and recommendations for organizations. However, many publications in the business ethics literature do not present, refer to or acknowledge any particular view of organizations or individuals. Without making such a view explicit, we cannot fully understand presented models and findings. This paper is therefore also an attempt to encourage business ethics scholars to account for their view and to seek to seek out views that would be helpful in understanding ethical an unethical behavior of organizations and their constituents.

A second contribution of this paper is the development of the concept of struggle, which to date has not received systematic attention in the business ethics literature. The proposed concept of a struggle is an essential part of organizations and individuals. It contributes to a more balanced approach to business ethics in at least three ways. The theory of struggle places the ethics of individuals and organizations on a continuum. The Bad Apple and Bad Barrel theory of Treviño and Youngblood (1990) treats individuals (the apples) and organizations (the barrels) as either good or bad. The proposed theory and concept of struggle view individuals and organizations as both good and bad, and the difference between being and doing more good than bad as something best understood in terms of a continuum.

The theory of struggle is also more balanced in the sense that it views ethical norms as dynamic. Behavioral business 
ethics theories, for example, often perceive ethical norms as static or treat them as given (see Treviño et al. 2006). This, however, neglects the emergence of new ethical norms and risks organizations failing to acknowledge, adopt, and implement them. Struggle theory pays attention to the challenges involved in adopting these new norms, and how it can lead to unethical behavior.

A struggle theory is finally also more balanced in that it does not shy away from those features of organizations that are intractable. Ethical dilemmas receive much attention in the business ethics literature. However, the approach to dealing with these dilemmas is usually rational, in the sense of developing arguments for solving them. The theory of struggle also addresses the emotional and psychological dimensions of ethical dilemmas and behavior, through acknowledging the fears, uncertainties, and the pain that come into play. The way in which organizations are advised to manage ethics can be described as relatively clinical, in the sense that organizations are advised to adopt an ethics program consisting of a limited number of instruments (Weaver and Treviño 1999) which should be implemented in a straightforward manner (Treviño and Weaver 2001) and supported by management (Weaver et al. 1999b). The theory of struggle emphasizes the challenges involved in embedding and maintaining an ethics program and treats it, not as a linear process, but as an iterative process of winning, stagnation, loss, and recovery that requires wrestling and muddling through. In their research among ethics officers, Treviño et al. (2014) helpfully already hint at the clashes, challenges, and difficulties they face in their function.

A struggle theory of ethics also has the potential to contribute to institutional theory. Institutional theory focusses on organizations' response to institutional norms and normative pressures (DiMaggio and Powell 1983; Meyer and Rowan 1977; Scott 1997), which is another type of pressure (the direction of which is more desirable) than the one operationalized in this paper. The concept of decoupling is central here and refers to the gaps that arise between symbolically adopted formal policies and actual organizational practice (Meyer and Rowan 1977; Oliver 1991). Although institutional norms are not by definition ethical and ethical norms are not necessarily institutionalized, the concept of struggle helps to explain why decoupling occurs. Decoupling points to the existence of an ethics gap, while an organization pretends that there is no ethics gap, and it can be the result of a lack of combativeness in organizations or individuals, and a failure to struggle sufficiently or adequately as a result. Decoupling in this case would be the result of a failure to struggle or a struggle that has been lost, which carries the risk of more unethical behavior, like misrepresentation, lies, and fraud being required to hide the gap, thus increasing the already existing ethics gap. In that sense, decoupling is not necessarily, as Tilcsik (2010) suggests, a state of affairs favored by management; it can also be the result of exhaustion or desperation or denial of the need for struggle. Accordingly, struggle theory explains why organizations have the ability to recouple.

A theory of struggle also has the potential to contribute to the theories of self-regulation, also called self-control or self-efficacy, as developed in the discipline of psychology. This paper has drawn on these theories to develop a theory of struggle as these theories are also concerned with the way in which individuals deal with temptations. The contribution of struggle theory as presented in this paper is that it not only focusses on individuals but also on the conditions in organizations that enable individual employees to struggle. This interplay has thus far not been addressed (cf. Vohs and Baumeister 2011). A struggle theory for organizations also opens the door to studying not only how individuals but also groups of individuals, like teams and units, deal with temptations. Moreover, self-regulation theory focuses on existing norms and how to deal with temptations that undermine the realization of these norms. The presented struggle theory also highlights the emergence of new norms that may require different strategies for dealing with temptations and pressures. Another potential contribution is that the proposed characteristics of combativeness presented in this paper are richer than the characteristics of self-control and self-regulation that have been proposed to date by, for example, Vohs and Baumeister (2011). Characteristics such as wisdom and moral conviction may add explanatory power to self-control. As such, combativeness is not just a moral muscle-it encompasses the mind, heart, and soul.

\section{Scientific Implications}

A theory of struggle has multiple implications. One of the implications is that if there is no struggle, an organization is at risk of an ethics gap arising. Due to the fact that we live in an imperfect world, it is impossible to always fully meet the legitimate interests of all stakeholders. Struggle is therefore not only ethical, but it also implies that the absence of struggle is unethical. It is unethical in the sense that the absence of struggle indicates that not enough effort is being made to realize the legitimate interests and expectations of stakeholders. This, however, is not to imply that the more an organization or individual struggles, the more ethical they are. Whether a struggle is more or less laudable depends on, for example, whether the struggle is recurring or novel. It is more laudable when an employee struggles with accepting or refusing a bribe for the first time than when the struggle occurs every time the same type of bribe is offered. This is because it shows a lack of 
growth in combativeness or lack of ability to learn from experience and devise an effective strategy to eliminate pressures and temptations.

That struggling is ethical is also not to imply that a struggle cannot be unethical. Organizations and individuals can, for example, struggle too much. According to Aristotle (Rowe and Broadie 2002), every virtue is the mean between two vices. Hence, combativeness is the mean between cowardice and zealotry. To argue that struggling is ethical does not mean that one should always be struggling, and as much as possible. The art of struggling also requires knowing when not to struggle (any longer). In this regard, Oliver (1991) notes how organizations can overreact when they are confronted with unethical behavior. Furthermore, it is also possible for organizations and individuals to struggle in a manner that is unethical. To say that struggling is ethical is not to suggest that all means to this end are ethical, as the end does not justify the means (cf. Kant 1785/2002). Hence, struggling through lying, intimidation, and disrespect is not ethical. A struggle is also unethical when it is motivated by unethical reasons (such as revenge), aimed toward unethical goals, or when then the struggle is merely an end in itself.

To stress the importance of the concept of struggle is not to imply that struggling is the explanation for and solution to all unethical behavior. Pressures and temptations may be so great that any struggle would fail. Moreover, unethical behavior can occur even in the absence of pressures and temptations, for example, due to ignorance (cf. Treviño et al. 2006). Neither does the concept of struggle suggest that there can be no ethical behavior without struggle. Ethical behavior can also occur, for example, out of habit, as Aristotle (Rowe and Broadie 2002) argued.

The proposed struggle theory and its propositions offer possibilities for follow-up research. Relevant in this regard is how to assess the different constructs. Although this paper identifies and defines different aspects, more work is needed to render them measurable. For example, as in the case of the different dimensions of the CEV model (cf. Kaptein 2011), organizational combativeness could be measured by means of a survey. The same applies to individual combativeness which can be measured through self-assessments or an assessments performed by others. The size of ethics gaps could also be measured by means of a survey. However, existing scales for surveying unethical behavior, such as of Kaptein (2008), contain static norms. The intensity of struggling can be measured, for example, by assessing the functioning of the brains (Heatherton and Wagner 2011).

This paper offers a simple model of struggling for individuals and organizations. As for the antecedents of struggling, new research may focus on what explains the combativeness of organizations, to what extent the combativeness between organizations differs, and the different patterns in the development of the combativeness of organizations. Follow-up research may also focus on how each of the different characteristics of combativeness contributes to the other aspects of combativeness, as well as the overall combativeness, and how organizational and individual combativeness are related to each other. Is organizational clarity, for example, mainly related to individual wisdom, organizational role modeling mainly related to strong moral convictions, and organizational achievability mainly related to individual willpower? A relevant question is also to what extent we can expect combativeness of organizations and individuals. For example, Gini (2011) posits that courage is not a superhuman virtue or indicative of supernumerary. In the model developed in this paper, training and practice were suggested as a way to develop the combativeness of organizations and individuals. Future research may also try to find other instruments for this. Regarding struggling itself, a crucial question is what type of struggle is needed in which situation. How do we explain or determine which strategy is the most effective? More in-depth knowledge is also needed to understand how struggles develop. Regarding the consequences of struggle, we focused on ethical consequences and combativeness. Other consequences of struggling can also be considered, such as the psychological effect it has on individuals. Lachman (2007) posits that personal sacrifice is often accompanied by a sense of peace because the individual stood up for a nonnegotiable principle. Kelly (1998), however, found that the struggle of nurses to preserve their moral integrity resulted in moral stress. Another possible consequence of struggle is that it can elicit a reaction from opposing forces. They can fight back (cutting budgets or spreading gossip), use larger 'weapons' (e.g., making threats of job-cuts), or direct their attention to less combative organizations or individuals (e.g., offering bribes to one employee after the other until one accepts).

This paper has developed a struggle theory for ethical behavior. The concept of struggle is already being used in relation to other management issues such as power (Fligstein 1987), control (Freeland 2001), maladies (Koerner 2014), disputes (Keltner 1994), ambiguity (Alvesson 1993), competition (Hunt and Morgan 1996), and talent management (McDonnell et al. 2011). However, to date no theory or model exist that explains the nature of struggle on organizational and individual level and what its antecedents and consequences are. Future research may therefore examine to what extent the proposed ethical struggle theory can be applied to these issues, as well as other issues that require great efforts such as innovation, efficiency, and strategy development. 


\section{Implications for Management}

The main idea of this paper is that in order for organizations to be and to remain ethical, struggle is required, because without, the ethics of an organization is at risk. This requires that the individuals that constitute organizations develop the virtue of combativeness. For management, adopting the theory of struggle implies viewing their organization as a battlefield, not in the sense of the frequently used metaphor or competing with and beating competitors (e.g., Prahalad 1999), but a battlefield consisting of pressures and temptations that need to be conquered so as to defend ethics and realize the good. This also implies a view of employees and management as potential victims and victors of opposing forces within and outside themselves and the organization.

A struggle approach has implications for ethical leadership, which is usually defined as visibly adhering to ethical norms and creating the conditions for followers to comply with those norms (Brown and Treviño 2006). In the framework of struggle theory, ethical leadership also concerns defining new ethical norms. Just following prevailing ethical norms amounts to maintenance. If managers want to be ethical leaders they should be alert to and anticipate developments and issues that will require new ethical norms and come up with ethical norms addressing these in advance. Ethical leadership does not require managers to be in the first row on the front (like generals in the army should not be in the first row in a battle). However, the manager perhaps occupies the position most exposed to pressures and temptations, which requires them to struggle the most. At the same time, when they are selected on their ethical combativeness they should be the ones with the least difficulty dealing with pressures and temptations. Another implication for ethical leadership is not to expect managers to act like saints (Alvesson 2011). A struggle theory recognizes that all individuals possess a mixture of good and bad inclinations and no one is exempt from facing difficulties or even suffering defeat when dealing with pressures and temptations. Without rationalizing giving into pressures and temptations, managers could be more open about their struggles so that others can learn from them and they from others.

A struggle theory has specific implications for those whose main function in an organization is to struggle for ethics. Those persons, such as ethics officers, run the risk of becoming frustrated, annoyed, or desperate. A view of ethics as struggle is encouraging in that it offers skills to deal with adversities and obstacles. Given the imperfect nature of organizations and human beings, and the possibility that a struggle may fail, it is unrealistic to expect all conditions to be in place and all behavior always to be ethical. An ethics officer that gets so frustrated about the lack of cooperation in their organization that they step down may have had too optimistic a view of ethics in business. If being ethical were easy and simple, the management of ethics and the function of ethics officer would not be necessary. An ethics officer exists because of the need to struggle for attention, time and budget. Such a struggle does not undermine their legitimacy, as Treviño et al. (2014b) suggest, but demonstrates it.

A struggle theory also has implications for the ethics program an organization runs. Implementing an ethics program is not just a matter of using the right measures ('weapons'). It is also a matter of putting effort into deciding which measures to take (e.g., convincing management that a code is desirable), their content (e.g., persuading management about the content of a code), implementing them (e.g., convincing managers and employees to change their behavior), and ensuring that they are effective (e.g., convincing managers to periodically monitor adherence to the code in their unit). As mentioned above, there is a always the risk that once an ethics program is in place and unethical behavior is not at the forefront of everyone's minds, the ethics program is neglected until unethical behavior becomes a significant issue again. Management should therefore not become complacent or reduce time and effort invested in an ethics program because no major incidents have occurred for some time. Indeed, the absence of a pressing need to address (the frequency of) unethical behavior testifies to the effectiveness of the investment in a particular ethics program.

A struggle theory also has implications for ethics training. Many organizations use e-learning methods to train their managers and employees in ethics (KPMG 2014). Others run classroom sessions in which they train managers and employees in analyzing and solving dilemma scenarios presented to them. Although these methods could be effective (Warren et al. 2014), it does not fully train employees in struggling, as these methods do not face participants with real consequences, and therefore the fears, pain and suffering of a struggle. Struggle theory emphasizes learning by doing. This means that it is important that organizations provide their managers and employees ethics training on the job through the use of check-ins, time-outs, interim reflections, feedback and feedforward, and coaching. Warner et al. (2011) have found some evidence that ethics training for soldiers during combat leads to a decline in unethical behavior. McKee and Ntoumanis (2014) also show how an intervention program promoting self-regulatory skills could lead to improved weight loss. The need for training, or experience, also suggests that people should not prematurely be appointed to functions that are subject to great pressures and temptations. Human Resource Management can assist by conducting assessments of the combativeness of 
applicants and measuring the results against the pressures and temptations of the function in question. If an organization still wishes to develop the combativeness of employees in a laboratory situation, gaming could potentially be considered given its proximity to real-life situations (Littlejohn and Pegler 2014).

Viewing ethics as a struggle also has consequences for the controls in an organization. Controls are meant to reduce the pressures and temptations in a function (Simons and Chabris 1999). For example, the control of dual signing to authorize an invoice reduces the temptation to commit fraud. Katz-Navon et al. (2005) argue that there should be a balance between rules and autonomy because too many rules reduce people's sense of responsibility. A struggle theory extends this argument by holding that people who are faced with too few pressures and temptations will struggle too little and become less combative. When, for example, an organization adopts a three-lines-of-defense compliance model, where the first line is management and their units; the second line is staff like quality, safety, legal, finance, and compliance; and the third line is audit; it runs the risk that when the second line is given too much authority, the first line feels less responsible for ethics and becomes reactive and less combative. Therefore, organizations should actively seek a balance between exposing managers and employees to pressures and temptations and protecting them against pressures and temptations.

For management and employees, it is ultimately important how they approach struggle in their daily work. This paper has presented a spectrum of five strategies. To determine which strategy would be best suited to a particular situation, and how such a strategy is to be operationalized into successful tactical interventions, however, will require further research.

Open Access This article is distributed under the terms of the Creative Commons Attribution 4.0 International License (http://crea tivecommons.org/licenses/by/4.0/), which permits unrestricted use, distribution, and reproduction in any medium, provided you give appropriate credit to the original author(s) and the source, provide a link to the Creative Commons license, and indicate if changes were made.

\section{References}

Adams, G. B., \& Balfour, D. L. (1998). Unmasking administrative evil (Vol. 5). Thousand Oaks: Sage Publications.

Albrecht, W., Albrecht, C., Albrecht, C., \& Zimbelman, M. (2008). Fraud examination. Boston: Cengage Learning.

Alvesson, M. (1993). Organizations as rhetoric: Knowledge-intensive firms and the struggle with ambiguity. Journal of Management Studies, 30(6), 997-1015.

Alvesson, M. (2011). Leaders as saints: Leadership through moral peak performance. In M. Alvesson \& A. Spicer (Eds.), Metaphors we lead by: Understanding leadership in the real world (pp. 51-75). London: Routledge.
Armitage, C. J., Wright, C. L., Parfitt, G., Pegington, M., Donnelly, L. S., \& Harvie, M. N. (2014). Self-efficacy for temptations is a better predictor of weight loss than motivation and global selfefficacy: Evidence from two prospective studies among overweight/obese women at high risk of breast cancer. Patient education and counseling, 95(2), 254-258.

Asch, S. E. (1955). Opinions and social pressure. Scientific American, 193(5), 31-35.

Ashforth, B. E., \& Anand, V. (2003). The normalization of corruption in organizations. Research in Organizational Behavior, 25, $1-52$.

Ayadi, N., Giraud, M., \& Gonzalez, C. (2013). An investigation of consumers' self-control mechanisms when confronted with repeated purchase temptations: Evidence from online private sales. Journal of Retailing and Consumer Services, 20(3), 272-281.

Azar, O. H., Yosef, S., \& Bar-Eli, M. (2013). Do customers return excessive change in a restaurant?: A field experiment on dishonesty. Journal of Economic Behavior \& Organization, 93, 219-226.

Badaracco, J, Jr. (1997). Defining moments: When managers must choose between right and right. Verlag: Harvard Business Press.

Badaracco, J, Jr. (2013). The good struggle: Responsible leadership in an unforgiving world. Verlag: Harvard Business Press.

Bandura, A. (1977). Social learning theory. Englewood Cliffs: Prentice Hall.

Bandura, A. (1994). Self-efficacy. New York: John Wiley \& Sons Inc.

Bandura, A. (1999). Moral disengagement in the perpetration of inhumanities. Personality and Social Psychology Review, 3(3), 193-209.

Barnes, C. M., Schaubroeck, J., Huth, M., \& Ghumman, S. (2011). Lack of sleep and unethical conduct. Organizational Behavior and Human Decision Processes, 115(2), 169-180.

Baucus, M. S., \& Near, J. P. (1991). Can illegal corporate behavior be predicted? An event history analysis. Academy of Management Journal, 34(1), 9-36.

Baumeister, R. F., \& Exline, J. J. (1999). Virtue, personality, and social relations: Self-Control as the moral muscle. Journal of Personality, 67(6), 1165-1194.

Baumeister, R. F., \& Exline, J. J. (2000). Self-control, morality, and human strength. Journal of Social and Clinical Psychology, 19(1), 29-42.

Baumeister, R. F., \& Heatherton, T. F. (1996). Self-regulation failure: An overview. Psychological inquiry, 7(1), 1-15.

Boekaerts, M., Pintrich, P. R., \& Zeidner, M. (Eds.). (2005). Handbook of self-regulation. Burlington: Elsevier.

Boulding, K. E. (1962). Conflict and defense: A general theory. Oxford: Harper.

Brown, K. W., \& Ryan, R. M. (2003). The benefits of being present: Mindfulness and its role in psychological well-being. Journal of Personality and Social Psychology, 84(4), 822-848.

Brown, M. E., \& Treviño, L. K. (2006). Ethical leadership: A review and future directions. The Leadership Quarterly, 17(6), 595-616.

Brown, M. E., Treviño, L. K., \& Harrison, D. A. (2005). Ethical leadership: A social learning perspective for construct development and testing. Organizational Behavior and Human Decision Processes, 97(2), 117-134.

Calhoun, C. (1995). Standing for something. The Journal of Philosophy, 92, 235-260.

Carr, D. (1988). The cardinal virtues and Plato's moral psychology. The Philosophical Quarterly, 38, 186-200.

Christian, M. S., \& Ellis, A. P. (2011). Examining the effects of sleep deprivation on workplace deviance: A self-regulatory perspective. Academy of Management Journal, 54(5), 913-934.

Ciulla, J. B. (2011). Is business ethics getting better? A historical perspective. Business Ethics Quarterly, 21(2), 335-343. 
Clarke, P. 2013. Young bankers struggle with ethics. Published on http://www.news.efinancialcareers.com.

Cressey, D. R. (1953). Other people's money; A study of the social psychology of embezzlement. Glencoe: Free Press.

Cyert, R. M., \& March, J. G. (1963). A behavioral theory of the firm. New York: Englewood Cliffs.

De Cremer, D., Van Dijk, E., \& Folmer, C. R. (2009). Why leaders feel entitled to take more: Feelings of entitlement as a moral rationalization strategy. In D. De Cremer (Ed.), Psychological perspectives on ethical behavior and decision making ( $\mathrm{pp}$. 107-119). Charlotte: Information Age Publishing.

De Ridder, D., \& de Wit, J. (Eds.). (2006). Self-regulation in health behavior. Chichester: John Wiley \& Sons.

De Ridder, D. T., Lensvelt-Mulders, G., Finkenauer, C., Stok, F. M., \& Baumeister, R. F. (2012). Taking stock of self-control a metaanalysis of how trait self-control relates to a wide range of behaviors. Personality and Social Psychology Review, 16(1), 76-99.

Dey, C. (2007). Social accounting at Traidcraft plc: A struggle for the meaning of fair trade. Accounting, Auditing \& Accountability Journal, 20(3), 423-445.

DiMaggio, P. J., \& Powell, W. W. (1983). The iron cage revisited: Institutional isomorphism and collective rationality in organizational fields. American Sociological Review, 48, 147-160.

Dohm, F. A., Beattie, J. A., Aibel, C., \& Striegel-Moore, R. H. (2001). Factors differentiating women and men who successfully maintain weight loss from women and men who do not. Journal of Clinical Psychology, 57(1), 105-117.

Donaldson, T., \& Dunfee, T. W. (1994). Toward a unified conception of business ethics: Integrative social contracts theory. Academy of Management Review, 19(2), 252-284.

Dovidio, J. F., Piliavin, J. A., Schroeder, D. A., \& Penner, L. (2006). The social psychology of prosocial behavior. Mahwah: Lawrence Erlbaum Associates Publishers.

Duska, R. (2000). Business ethics: Oxymoron or good business? Business Ethics Quarterly, 10, 111-129.

Erikson, E. H. (1993). Childhood and society. New York: WW Norton \& Company.

Etzioni, A. (1998). A communitarian note on stakeholder theory. Business Ethics Quarterly, 8(4), 679-691.

Fashion United 2014. H\&M's struggle for ethical and sustainable fashion. Published on: http://www.myretailmedia.com.

Ferrell, O. C., \& Fraedrich, J. (2014). Business ethics: Ethical decision making \& cases. Boston: Cengage Learning.

Fishbach, A., \& Converse, B. A. (2010). Identifying and battling temptation. Handbook of self-regulation: Research, Theory and Applications, 2, 244-260.

Fishbach, A., \& Shah, J. Y. (2006). Self-control in action: implicit dispositions toward goals and away from temptations. Journal of Personality and Social Psychology, 90(5), 820-832.

Fligstein, N. (1987). The intraorganizational power struggle: Rise of finance personnel to top leadership in large corporations, 1919-1979. American Sociological Review, 52, 44-58.

Freeland, R. F. (2001). The struggle for control of the modern corporation: Organizational change at General Motors, 1924-1970 (Vol. 17). Cambridge: Cambridge University Press.

Freeman, R. E. (1984). Strategic management: A stakeholder approach. Boston: Pitman.

Gailliot, M. T., \& Baumeister, R. F. (2007). The physiology of willpower: Linking blood glucose to self-control. Personality and Social Psychology Review, 11(4), 303-327.

Gailliot, M. T., Plant, E. A., Butz, D. A., \& Baumeister, R. F. (2007). Increasing self-regulatory strength can reduce the depleting effect of suppressing stereotypes. Personality and Social Psychology Bulletin, 33(2), 281-294.

Gini, A. (2011). Moral courage in organizations: Doing the right thing at work. In D. R. Comer \& G. Vega (Eds.), Moral courage in organizations: Doing the right thing at work (pp. 3-12). New York: ME Sharpe.

Gino, F., Schweitzer, M. E., Mead, N. L., \& Ariely, D. (2011). Unable to resist temptation: How self-control depletion promotes unethical behavior. Organizational Behavior and Human Decision Processes, 115(2), 191-203.

Gintis, H., Bowles, S., Boyd, R., \& Fehr, E. (2003). Explaining altruistic behavior in humans. Evolution and Human Behavior, 24(3), 153-172.

Gladwin, T. N., Kennelly, J. J., \& Krause, T. S. (1995). Shifting paradigms for sustainable development: Implications for management theory and research. Academy of Management Review, 20(4), 874-907.

González-Benito, J., \& González-Benito, Ó. (2010). A study of determinant factors of stakeholder environmental pressure perceived by industrial companies. Business Strategy and the Environment, 19(3), 164-181.

Goodstein, J., Butterfield, K. D., Pfarrer, M. D., \& Wicks, A. C. (2014). Individual and organizational reintegration after ethical or legal transgressions: Challenges and opportunities. Business Ethics Quarterly, 24(3), 315-342.

Gottfredson, M. R., \& Hirschi, T. (1990). A general theory of crime. Stanford: Stanford University Press.

Graafland, J., Kaptein, M., \& Mazereeuw-van der Duijn Schouten, C. (2006). Business dilemmas and religious belief: An explorative study among Dutch executives. Journal of Business Ethics, 66(1), 53-70.

Graetz, M. J., \& Mashaw, J. L. 1994. Ethics, institutional complexity and health care reform: The struggle for normative balance. Faculty Scholarship Series Yale Law School Faculty Scholarship.

Greene, R. (2007). The 33 strategies of war. London: Profile Books.

Hambrick, D. C., \& Snow, C. C. 1977. A contextual model of strategic decision making in organizations. In Academy of management proceedings (pp. 109-112). Academy of Management.

Hamilton, J. B, I. I. I., \& Hoch, D. (1997). Ethical standards for business lobbying: Some practical suggestions. Business Ethics Quarterly, 7, 117-129.

Hampden-Turner, C. M., \& Trompenaars, F. (2008). Building crosscultural competence: How to create wealth from conflicting values. New Haven: Yale University Press.

Hannah, S. T., Avolio, B. J., \& Walumbwa, F. O. (2011). Relationships between authentic leadership, moral courage, and ethical and pro-social behaviors. Business Ethics Quarterly, 21(4), 555-578

Heatherton, T. F., \& Wagner, D. D. (2011). Cognitive neuroscience of self-regulation failure. Trends in Cognitive Sciences, 15(3), 132-139.

Hering, C. (1997). Beyond understanding? Some thoughts on the meaning and function of the notion of 'evil'. British Journal of Psychotherapy, 14(2), 209-220.

Heuser, B. (2010). The evolution of strategy: Thinking war from antiquity to the present. Cambridge: Cambridge University Press.

Hill, C. W., \& Jones, T. M. (1992). Stakeholder-agency theory. Journal of Management Studies, 29(2), 131-154.

Hobbes, T. (1928). Leviathan, or the matter, forme and power of a commonwealth ecclesiasticall and civil. New Haven: Yale University Press.

Hudson, R. (2005). Ethical investing: Ethical investors and managers. Business Ethics Quarterly, 15(4), 641-657.

Hume, D. (2012). A treatise of human nature. New York: Courier Dover Publications.

Hunt, S. D., \& Morgan, R. M. (1996). The resource-advantage theory of competition: dynamics, path dependencies, and evolutionary dimensions. The Journal of Marketing, 60, 107-114. 
Jaffee, D. (2010). Fair trade standards, corporate participation, and social movement responses in the United States. Journal of Business Ethics, 92(2), 267-285.

Janssens, M., \& Kaptein, M. (2014). The ethical responsibility of companies toward animals: A study of the expressed commitment of the Fortune Global 200. Available at SSRN.

Jardine, D. W., McCaffrey, G., \& Gilham, C. (2014). The pedagogy of suffering: Four fragments. Paideusis, 21(2), 4-12.

Jones, G. R., \& George, J. M. (1998). The experience and evolution of trust: Implications for cooperation and teamwork. Academy of Management Review, 23(3), 531-546.

Kahneman, D. (1973). Attention and effort. Englewood Cliffs: Prentice-Hall.

Kant, I. (1785/2002). Groundwork for the metaphysics of morals. New Haven: Yale University Press.

Kaptein, M. (2008). Developing a measure of unethical behavior in the workplace: A stakeholder perspective. Journal of Management, 34(5), 978-1008.

Kaptein, M. (2011). Understanding unethical behavior by unraveling ethical culture. Human Relations, 64(6), 843-869.

Kaptein, M., \& Wempe, J. (2002). The balanced company: A theory of corporate integrity. Oxford: Oxford University Press.

Katz-Navon, T., Naveh, E., \& Stern, Z. (2005). Safety climate in health care organizations: a multidimensional approach. Academy of Management Journal, 48(6), 1075-1089.

Keizer, K. 2010. The spreading of disorder. University of Groningen: $\mathrm{Ph} . \mathrm{D}$. thesis.

Kelly, B. (1998). Preserving moral integrity: A follow-up study with new graduate nurses. Journal of Advanced Nursing, 28(5), 1134-1145.

Keltner, J. W. (1994). The management of struggle: Elements of dispute resolution through negotiation, mediation, and arbitration. Creeskill: Hampton Press.

Kerr, S. (1975). On the folly of rewarding A, while hoping for B. Academy of Management Journal, 18(4), 769-783.

Kidder, R. M. (2005). Moral courage. New York: W. Morrow.

Kinneging, A. A. M. (2009). A geography of good and evil. Philosophical investigations. Boston: Prentice Hall.

Koerner, M. M. (2014). Courage as identity work: Accounts of workplace courage. Academy of Management Journal, 57(1), 63-93.

KPMG. (2014). The business codes of the fortune global 200. Amsterdam: KPMG.

Lachman, V. D. (2007). Moral courage: A virtue in need of development? Medsurg Nursing, 16(2), 131-133.

LaRose, R., \& Eastin, M. S. (2002). Is online buying out of control? Electronic commerce and consumer self-regulation. Journal of Broadcasting \& Electronic Media, 46(4), 549-564.

Lawrence, T. B., \& Maitlis, S. (2012). Care and possibility: Enacting an ethic of care through narrative practice. Academy of Management Review, 37(4), 641-663.

Leibniz, G. W. (2000). Theodicy: Essays on the goodness of God, the freedom of man and the origin of evil. New York: Wipf and Stock Publishers.

Littlejohn, A., \& Pegler, C. (2014). Preparing for blended e-learning. New York: Routledge.

Litzky, B. E., Eddleston, K. A., \& Kidder, D. L. (2006). The good, the bad, and the misguided: How managers inadvertently encourage deviant behaviors. The Academy of Management Perspectives, 20(1), 91-103.

Liu, X., Vredenburg, H., \& Steel, P. (2014). A meta-analysis of factors leading to management control in international joint ventures. Journal of International Management, 20, 219-236.

Machiavelli, N. (1992). The prince. New York: Dover Publications Inc.
MacIntyre, A. (1984). After virtue. Notre Dame: University of Notre Dame Press.

MacLean, T. L., \& Behnam, M. (2010). The dangers of decoupling: The relationship between compliance programs, legitimacy perceptions, and institutionalized misconduct. Academy of Management Journal, 53(6), 1499-1520.

Martin, K. D., Cullen, J. B., Johnson, J. L., \& Parboteeah, K. P. (2007). Deciding to bribe: A cross-level analysis of firm and home country influences on bribery activity. Academy of Management Journal, 50(6), 1401-1422.

Masicampo, E. J., \& Baumeister, R. F. (2007). Relating mindfulness and self-regulatory processes. Psychological Inquiry, 18(4), 255-258.

Mazar, N., \& Ariely, D. (2006). Dishonesty in everyday life and its policy implications. Journal of Public Policy \& Marketing, 25(1), 117-126.

Mazar, N., \& Zhong, C. B. (2010). Do green products make us better people? Psychological Science, 21, 494-498.

McDonnell, A., Hickey, C., \& Gunnigle, P. (2011). Global talent management: Exploring talent identification in the multinational enterprise. European Journal of International Management, 5(2), 174-193.

McKee, H. C., \& Ntoumanis, N. 2014. Developing self-regulation for dietary temptations: intervention effects on physical, self-regulatory and psychological outcomes. Journal of Behavioral Medicine, 37(6), 1075-1081.

Mead, N. L., Baumeister, R. F., Gino, F., Schweitzer, M. E., \& Ariely, D. (2009). Too tired to tell the truth: Self-control resource depletion and dishonesty. Journal of Experimental Social Psychology, 45(3), 594-597.

Messadié, G. (1996). A history of the devil. New York: Kodansha International.

Meyer, J. W., \& Rowan, B. (1977). Institutionalized organizations: Formal structure as myth and ceremony. American Journal of Sociology, 83, 340-363.

Milgram, S. (1974). Obedience to authority: An experimental view. New York: HarperCollins.

Mitchell, R. K., Agle, B. R., \& Wood, D. J. (1997). Toward a theory of stakeholder identification and salience: Defining the principle of who and what really counts. Academy of Management Review, 22(4), 853-886.

Moberg, D. J. (1999). The big five and organizational virtue. Business Ethics Quarterly, 9, 245-272.

Moore, M. H. (1907). Phases of the commercial spirit. The Sewanee Review, 15(1), 31-40.

Moore, J. (1990). What is really unethical about insider trading? Journal of Business Ethics, 9(3), 171-182.

Moore, C., Detert, J. R., Klebe Treviño, L., Baker, V. L., \& Mayer, D. M. (2012). Why employees do bad things: Moral disengagement and unethical organizational behavior. Personnel Psychology, $65(1), 1-48$

Morgan, G. (1986). Images of Organization. Beverly Hills, CA: Sage Publications.

Muchlinski, P. (2012). Implementing the new UN corporate human rights framework: Implications for corporate law, governance, and regulation. Business Ethics Quarterly, 22(1), 145-177.

Muraven, M. (2010). Building self-control strength: Practicing selfcontrol leads to improved self-control performance. Journal of Experimental Social Psychology, 46(2), 465-468.

Muraven, M., Baumeister, R. F., \& Tice, D. M. (1999). Longitudinal improvement of self-regulation through practice: Building selfcontrol strength through repeated exercise. The Journal of Social Psychology, 139(4), 446-457.

Muraven, M., Shmueli, D., \& Burkley, E. (2006). Conserving selfcontrol strength. Journal of Personality and Social Psychology, 91(3), 524-537. 
Muraven, M., Tice, D. M., \& Baumeister, R. F. (1998). Self-control as a limited resource: Regulatory depletion patterns. Journal of Personality and Social Psychology, 74(3), 774-789.

Neville, B. A., \& Menguc, B. (2006). Stakeholder multiplicity: Toward an understanding of the interactions between stakeholders. Journal of Business Ethics, 66(4), 377-391.

Neiman, S. (2004). Evil in modern thought: An alternative history of philosophy. Princeton University Press.

Nichols, D., \& Subramaniam, C. (2001). Executive compensation: Excessive or equitable? Journal of Business Ethics, 29(4), 339-351.

Oaten, M., \& Cheng, K. (2007). Improvements in self-control from financial monitoring. Journal of Economic Psychology, 28(4), 487-501.

Ocasio, W. (1997). Towards an attention-based view of the firm. Strategic Management Journal, 18, 187-206.

Oliver, C. (1991). Strategic responses to institutional processes. Academy of Management Review, 16(1), 145-179.

Paine, L. (2002). Value shift: Why companies must merge social and financial imperatives to achieve superior performance. New York: McGraw Hill Professional.

Pascal, B. (1910). Thoughts (Vol. 48). New York: PF Collier \& Son.

Pearson, E. S. (2012). Goal setting as a health behavior change strategy in overweight and obese adults: A systematic literature review examining intervention components. Patient Education and Counseling, 87(1), 32-42.

Pfeffer, J., \& Salancik, G. R. (1978). The external control of organizations: A resource dependence approach. New York: Harper and Row Publishers.

Piderit, S. K. (2000). Rethinking resistance and recognizing ambivalence: A multidimensional view of attitudes toward an organizational change. Academy of Management Review, 25(4), 783-794.

Pitesa, M., \& Thau, S. (2013). Masters of the universe: How power and accountability influence self-serving decisions under moral hazard. Journal of Applied Psychology, 98(3), 550.

Prahalad, C. K. (1999). Changes in the competitive battlefield. Financial Times, 4, 1999.

Radin, T. J., \& Calkins, M. (2006). The struggle against sweatshops: Moving toward responsible global business. Journal of Business Ethics, 66(2-3), 261-272.

Rowe, C. J., \& Broadie, S. (Eds.). (2002). Nicomachean ethics. Oxford: Oxford University Press.

Schweitzer, M. E., Ordóñez, L., \& Douma, B. (2004). Goal setting as a motivator of unethical behavior. Academy of Management Journal, 47(3), 422-432.

Scott, W. R. (1997). Institutions and organizations. Thousand Oaks: Sage.

Sekerka, L. E., \& Bagozzi, R. P. (2007). Moral courage in the workplace: Moving to and from the desire and decision to act. Business Ethics: A European Review, 16(2), 132-149.

Shalit, B. (1988). The psychology of conflict and combat. Westport: Greenwood Publishing Group.

Shao, R., Aquino, K., \& Freeman, D. (2008). Beyond moral reasoning: A review of moral identity research and its implications for business ethics. Business Ethics Quarterly, 18, 513-540.

Shiffman, S. (1984). Coping with temptations to smoke. Journal of Consulting and Clinical Psychology, 52(2), 261-267.

Simons, D. J., \& Chabris, C. F. (1999). Gorillas in our midst: Sustained inattentional blindness for dynamic events. Perception, 28(9), 1059-1074.

Sims, R. (2009). Toward a better understanding of organizational efforts to rebuild reputation following an ethical scandal. Journal of Business Ethics, 90(4), 453-472.

Sims, R. R., \& Brinkmann, J. (2003). Enron ethics (or: culture matters more than codes). Journal of Business Ethics, 45(3), 243-256.
Sjöström, E. (2008). Shareholder activism for corporate social responsibility: What do we know? Sustainable Development, 16(3), 141-154.

Smith, A. (2009). The Wealth of Nations. Blacksburg: Thrifty books.

Spinoza, B. (1985). Metaphysical thoughts. In E. Curley (Ed.), The collected works of spinoza. Princeton: Princeton Press.

Staw, B. M., \& Boettger, R. D. (1990). Task revision: A neglected form of work performance. Academy of Management Journal, 33(3), 534-559.

Staw, B. M., \& Szwajkowski, E. (1975). The scarcity-munificence component of organizational environments and the commission of illegal acts. Administrative Science Quarterly, 20, 345-354.

Stevens, J. M., Steensma, H., Harrison, D. A., \& Cochran, P. L. (2005). Symbolic or substantive document? The influence of ethics codes on financial executives' decisions. Strategic Management Journal, 26(2), 181-195.

Tangen, K. 2003. Shell: Struggling to build a better world? Lysaker: FNI Report.

Tenbrunsel, A. E. (1998). Misrepresentation and expectations of misrepresentation in an ethical dilemma: The role of incentives and temptation. Academy of Management Journal, 41(3), 330-339.

Tenbrunsel, A. E., \& Messick, D. M. (2004). Ethical fading: The role of self-deception in unethical behavior. Social Justice Research, 17(2), 223-236.

Thomas, R., Sargent, L. D., \& Hardy, C. (2011). Managing organizational change: Negotiating meaning and power-resistance relations. Organization Science, 22(1), 22-41.

Tilcsik, A. (2010). From ritual to reality: Demography, ideology, and decoupling in a post-communist government agency. Academy of Management Journal, 53(6), 1474-1498.

Treviño, L. K., \& Brown, M. E. (2004). Managing to be ethical: Debunking five business ethics myths. The Academy of Management Executive, 18(2), 69-81.

Treviño, L. K., den Nieuwenboer, N. A., \& Kish-Gephart, J. J. (2014a). (Un) ethical behavior in organizations. Annual Review of Psychology, 65, 635-660.

Treviño, L. K., den Nieuwenboer, N. A., Kreiner, G. E., \& Bishop, D. G. (2014b). Legitimating the legitimate: A grounded theory study of legitimacy work among ethics and compliance officers. Organizational Behavior and Human Decision Processes, 123(2), 186-205.

Treviño, L. K., \& Weaver, G. R. (2001). Organizational justice and ethics program "follow-through": Influences on employees' harmful and helpful behavior. Business Ethics Quarterly, 11, 651-671.

Treviño, L. K., \& Weaver, G. R. (2003). Managing ethics in business organizations: Social scientific perspectives. Stanford: Stanford University Press.

Treviño, L. K., Weaver, G. R., \& Reynolds, S. J. (2006). Behavioral ethics in organizations: A review. Journal of Management, 32(6), 951-990.

Treviño, L. K., \& Youngblood, S. A. (1990). Bad apples in bad barrels: A causal analysis of ethical decision-making behavior. Journal of Applied Psychology, 75(4), 447-476.

Trope, Y., \& Fishbach, A. (2000). Counteractive self-control in overcoming temptation. Journal of Personality and Social Psychology, 79(4), 493-506.

Tyler, T. R., \& Blader, S. L. (2005). Can businesses effectively regulate employee conduct? The antecedents of rule following in work settings. Academy of Management Journal, 48(6), $1143-1158$.

Tyler, J. M., \& Burns, K. C. (2008). After depletion: The replenishment of the self's regulatory resources. Self and Identity, 7(3), 305-321. 
Van Tulder, R., Van Wijk, J., \& Kolk, A. (2009). From chain liability to chain responsibility. Journal of Business Ethics, 85(2), 399-412.

Velasquez, M. (2000). Globalization and the failure of ethics. Business Ethics Quarterly, 10(1), 343-352.

Vohs, K. D., \& Baumeister, R. F. (Eds.). (2011). Handbook of selfregulation: Research, theory, and applications. New York: Guilford Press.

Von Clausewitz, C. (2004). On war. Oxford: Digireads com Publishing.

Waddock, S. A., Bodwell, C., \& Graves, S. B. (2002). Responsibility: The new business imperative. The Academy of Management Executive, 16(2), 132-148.

Warner, C. H., Appenzeller, G. N., Mobbs, A., Parker, J. R., Warner, C. M., Grieger, T., \& Hoge, C. W. (2011). Effectiveness of battlefield-ethics training during combat deployment: A programme assessment. The Lancet, 378, 915-924.

Warren, D. E., Gaspar, J. P., \& Laufer, W. S. (2014). Is formal ethics training merely cosmetic? Business Ethics Quarterly, 24(1), 85-117.

Weaver, G. R., \& Treviño, L. K. (1999). Compliance and values oriented ethics programs. Business Ethics Quarterly, 9(2), 315-335.

Weaver, G. R., Treviño, L. K., \& Cochran, P. L. (1999a). Corporate ethics programs as control systems: Influences of executive commitment and environmental factors. Academy of Management Journal, 42(1), 41-57.

Weaver, G. R., Treviño, L. K., \& Cochran, P. L. (1999b). Integrated and decoupled corporate social performance: Management commitments, external pressures, and corporate ethics practices. Academy of Management Journal, 42(5), 539-552.

Weber, J., \& Getz, K. (2004). Buy bribes or bye-bye bribes: The future status of bribery in international commerce. Business Ethics Quarterly, 14(4), 695-711.

Weick, K. E. (1995). Sensemaking in organizations. Thousand Oaks: Sage.

Weick, K. E., \& Sutcliffe, K. M. (2006). Mindfulness and the quality of organizational attention. Organization Science, 17(4), 514-524.

Wertenbroch, K. (1998). Consumption self-control by rationing purchase quantities of virtue and vice. Marketing Science, 17(4), 317-337.

Westphal, J. D., \& Zajac, E. J. (2001). Decoupling policy from practice: The case of stock repurchase programs. Administrative Science Quarterly, 46(2), 202-228.

Wiseman, R. (2011). Quirkology. London: Pan Macmillan.

Woodard, C. R. (2004). Hardiness and the concept of courage. Consulting Psychology Journal: Practice and Research, 56(3), 173-185.

Zimbardo, P. (2007). The lucifer effect: Understanding how good people turn evil. New York: Random House. 